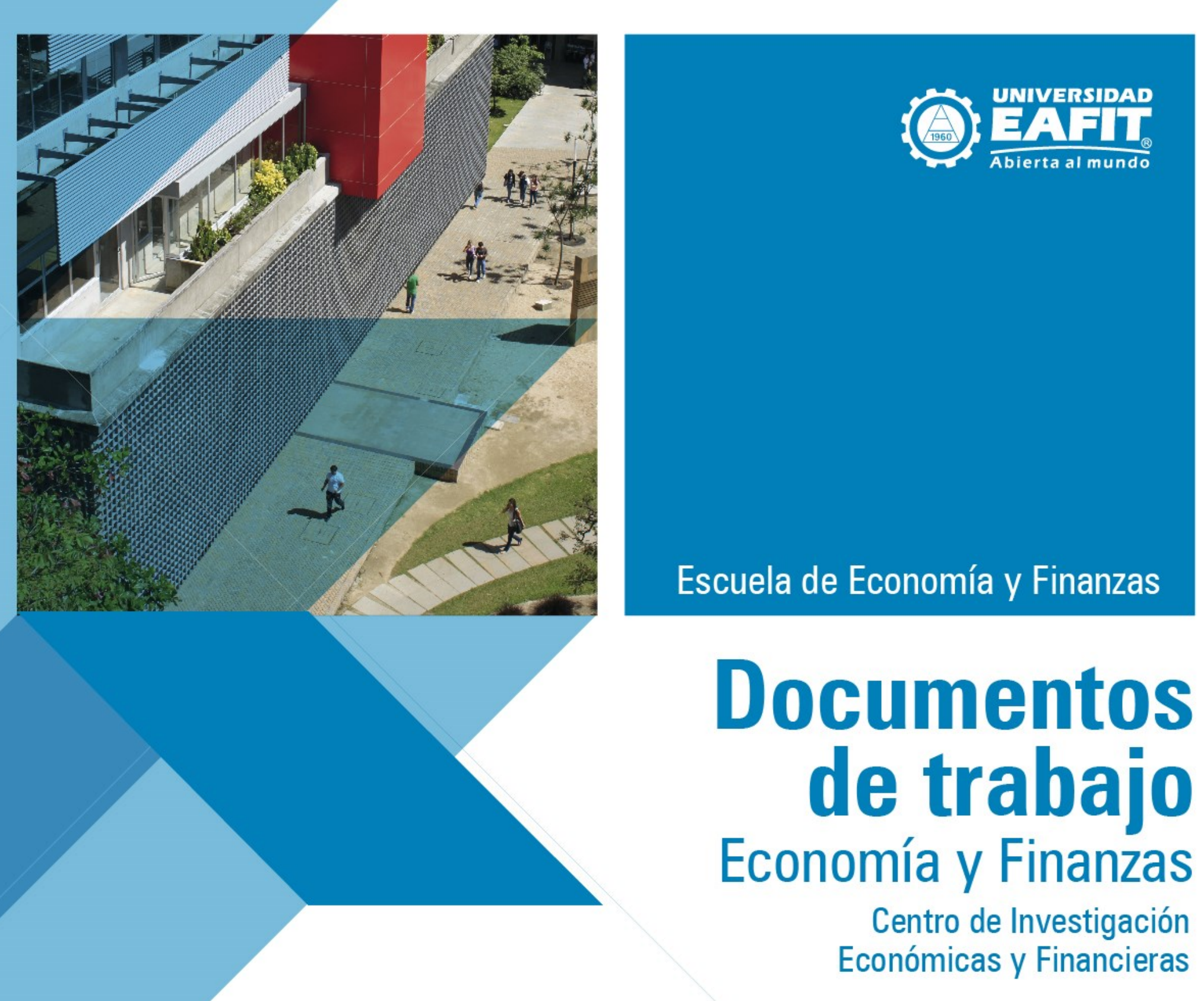

No. 14-27 Liquidity spillover effects of equity offerings 2014 over dual-class shares Vasco, Mateo; Agudelo, Diego A. 


\title{
Liquidity spillover effects of equity offerings over dual-class shares ${ }^{1}$
}

\author{
Mateo Vasco ${ }^{2} \quad$ Diego A. Agudelo
}

July, 2014

\begin{abstract}
We study the spillover effect from equity offerings over dual-class shares. Whereas, evidence has been found that a seasoned equity offering improves stock liquidity, the effect over the liquidity of different type shares of the same firm has not been explored. We use equity offerings of five Latin American countries: Brazil, Chile, Colombia, Mexico and Peru, during 1995 to 2012, because dual-class shares are widely used in the regions. In spite of the expected information asymmetry reduction, using panel data models we found a stock liquidity reduction of dual-class shares upon the offering; consistent with trading migration effects, according with the theory of inventory costs.
\end{abstract}

JEL Classification: G12, G14, G15.

Keywords: Stock liquidity; Equity offerings; Event studies; Emerging markets.

\section{Introduction}

As alternative shares of a given firm equity, dual-class shares typically have closely related cashflows, are exposed to similar market and idiosyncratic effects and compete for a very similar pool of investors. Thus, dual class stocks offer a natural control sample to test for differential effects, associated to property rights, trading, liquidity such as in Ang, Chua \& Jiang (2010), Levy (1983), Ødegaard (2007), Smith \& Amoako-Adu (1995), among others.

\footnotetext{
${ }^{1}$ This research was supported by Universidad EAFIT. We specially acknowledge the valuable suggestions of Diego A. Restrepo, Andrés Ramírez, Gustavo Canavire and the other participants of the regular MSc. in Finance Seminar of Universidad EAFIT.

${ }^{2}$ Corresponding author: Universidad EAFIT, Cr. 437 Sur - 50, Medellín, Colombia. Phone: +57-4 2619500.

E-mail: mvascoco@eafit.edu.co.

Both authors are at Finance Department, School of Economics and Finance, Center for Research on Economics and Finance (CIEF), Universidad EAFIT.
} 
Despite the worldwide use of dual-class shares, they have had different features across countries. In some countries they are banned, in other they are allowed but not listed, and in a few countries they are more similar to debt-like security. For example, in China, dual-class B shares allow foreign investors to participate in the stock market and buy a limited stake in Chinese companies. ${ }^{3}$ Meanwhile, in Latin America dual-class shares have been issued with similar cash-flows but limited political rights, to keep corporate control of traditional blockholders (Dyck \& Zingales, 2004; Masulis, Pham, \& Zein, 2011).

In this paper we study the effect of dual-class share offerings on the liquidity of a different type of share of the same issuer (henceforth called "associated dual-class share"). This relationship between equity offerings and dual-class stock liquidity has not been studied, to the extent of our knowledge.

The closest related literature study effects of seasoned equity offerings on liquidity and returns of the same security. Lease, Masulis \& Page (1991) find a buy-sell imbalance associated to an increase in trading volume and a decrease in bid-ask spreads, during SEOs in NYSE and AMEX. Similarly, Tripathy \& Rao (1992) find a significant decrease in bid-ask spreads after the offering date. They argue that this is due to a decrease of adverse selection costs because of the increased information gathered during the underwriting. Kothare (1997) also provides evidence of decreasing bid-ask spreads after SEOs in NASDAQ. She argues that this liquidity gain comes from reducing ownership concentration which decreases adverse selection costs that dealers assume for the probability of trading with informed investors. Eckbo, Masulis \& Norli (2000) also present evidence of a liquidity improvement after a SEO, but using turnover as proxy of liquidity instead of the liquidity measures widely accepted.

Providing an alternative explanations for post-SEO higher liquidity, Bilinski, Lui \& Strong (2012) show that the number of analysts following the firm increases significantly after the event, which can also mitigate adverse selections costs. Additionally, they show an increase in participation of institutional investors, both in number and ownership share, which is also a source of liquidity improvement, given that institutional investors are usually deemed to be non-informed liquidity investors that frequently rebalance their portfolio (Rubin, 2007). Reduction of information asymmetry upon a SEO is measured by Brooks \& Patel (2000) for NYSE and AMEX, and Kryzanowski, Lazrak $\&$ Rakita (2010) for TSX, who find a drop in the adverse selection component of the bid-ask spread.

Unlike these previous studies, we are not interested in the effect of a SEO over the liquidity of the issued share, but the effect that an equity offering (either SEO or IPO) has on other stocks of the

\footnotetext{
${ }^{3}$ For a complete survey of dual-class characteristics around the world and their relation with ownership structure, see Nenova $(2001,2003)$
} 
same issuer. This is particularly important to be studied in Latin American markets because of the wide use of dual-class shares. Dual-class shares have been extensively used in the region by controlling shareholders as a mechanism to raise capital while keeping control of the firm. Additionally, if one of the reasons to issue new equity is to reduce the cost of capital by making the company more visible and its share more liquid (Amihud \& Mendelson, 1986a, 1986b, 1988), managers should take into account the effect of new equity offerings on liquidity of other securities.

There are at least two expected and opposite liquidity spillover effects of equity offerings to the associated dual-class share. Firstly, the inventory costs theory of liquidity relate trading activity with liquidity (Amihud \& Mendelson, 1980; Grossman \& Miller, 1988; Ho \& Stoll, 1981, 1983). As the only considerable distinction between most of the different classes of shares in Latin America are vote rights (Doidge, 2004; Dyck \& Zingales, 2004; Nenova, 2001, 2003), we could expect that some minority institutional investors and noise traders replace the associated dual-class share with the recent issued share, reducing the frequency in which the latter is traded and, consequently, decreasing its liquidity. ${ }^{4}$ Secondly, from the evidence on the effects of SEOs mentioned above, the increased visibility associated with an equity offering and information revealed during the underwriting process, should also benefit the associated dual class share, with the consequent reduction in adverse selection cost and increase on liquidity. ${ }^{5}$

For this purpose, we run a panel-data model in event time to estimate the effect of an equity offering on the liquidity of associated dual-class shares, controlling for other well-known determinants of liquidity. We identify all equity offerings of Brazil, Chile, Colombia, Mexico and Peru during 1995 to 2012 of dual class-shares, and include a set of control samples, following a matching procedure.

The results supports the idea that an equity offering reduces liquidity of associated dual-class shares, suggesting that some investors migrate from the associated dual class share to the recently issued, and that this effect dominates any possible reduction in adverse selection costs due to new information revealed or higher visibility. This liquidity impairment is evidenced on two out of three liquidity proxies. The results are robust to different estimation methods.

The contribution of this paper to the literature is four-fold. First, this is the first research to study the liquidity impact of equity offerings on dual-class shares. Whereas it is well known that seasoned equity offerings improves liquidity of the issued shares, what happens with the other shares of the

\footnotetext{
${ }^{4}$ Evidence of a similar effect was supplied by Levine and Schmukler (2006), who find that trading migrates from the home emerging market to the US exchanges upon an ADR issuing.

${ }^{5}$ The adverse selection costs, explained as the lemons problem, was proposed by Akerlof (1970) and was linked to liquidity, theoretically, by Bagehot (1971), Copeland \& Galai (1983), Kyle (1985), Glosten \& Milgrom (1985), among others.
} 
same issuer had not been explored. Second, unlike the SEO literature mentioned above, we are able to include initial public offerings in our events, as we are interested in analyzing the behavior of shares different from the issued one. Third, this is one of the few existing studies that use an event study to analyze the change in stock liquidity. Moreover, we use a multivariate regression approach instead of the most common univariate analysis to draw more robust conclusions. Finally, studying the liquidity of Latin American dual class-shares is not only relevant because of the wide use of dualclass shares in the region, but also because lack of liquidity is a well-known barrier for the development of emerging markets. The detriment of liquidity of associated dual-class shares should be factored in the corporate decision of raising capital by equity issuing.

The paper is organized as follows. Section 2 describes the source of data, the computation of liquidity proxies and the empirical event design. In section 3 we present the econometric results. Section 4 concludes.

\section{Data and methodology}

The data on prices, quotes and volumes were collected on a stock daily basis from Datastream, beginning in January 1995 and ending December 2012 of all listed shares in the stock exchanges of Brazil, Chile, Colombia, Mexico and Peru. ${ }^{6}$ To mitigate the survivorship bias, we include current dead shares that used to be active in some period of time of the sample. This data will allow us to calculate various liquidity proxies and some control variables.

We compute log returns on daily basis with closing prices and the proportional bid-ask spread with quoted bid and ask prices. The bid-ask spread is one of our proxies of liquidity. The other two are: Amihud's impact price (Amihud, 2002) and Zero daily returns (Lesmond, Ogden, \& Trzcinka, 1999) which has already been tested as a good transaction costs proxy in emerging markets (Bekaert, Harvey, \& Lundblad, 2007; Lee, 2011). Bid-ask spread is calculated as in equation (1); we discarded bid-ask spreads greater than 0.8 (similar to Lesmond, 2005) and then averaged across each month for each stock.

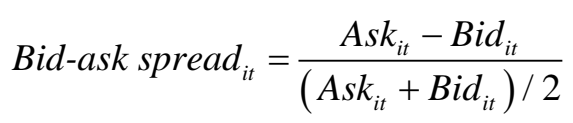

The Amihud's impact price measure was computed as in equation (2) in daily basis, winsorized at percentiles 1 and 99 and then averaged across each month.

${ }^{6}$ These are the Latin American countries classified as “emerging markets” by Morgan Stanley as of 2014. 


$$
\text { Amihud's measure }_{i t}=\frac{\mid \text { Return }_{i t} \mid}{{\text { Volume } \text { traded }_{i t}}}
$$

The Zero daily return measure was computed as the percentage of days within each month with zero return and positive volume, following Goyenko, Holden \& Trzcinka (2009).

Data of equity offerings comes from Bloomberg, and was matched with the database of prices, quotations and volume using the Sedol code. ${ }^{7}$ Table 1 presents the number of shares, equity offerings and equity offering of dual-class firms. The number of shares includes currently active and dead shares. Naturally, the biggest sample belongs to Brazil. The countries with higher proportion of dualclass offerings are Colombia and Mexico.

Table 1: Sample size per country

\begin{tabular}{lrrrrrr}
\hline Country & Brazil & \multicolumn{1}{c}{ Chile } & Colombia & Mexico & Peru & Total \\
\hline Number of shares & 1,100 & 315 & 187 & 335 & 316 & 2,253 \\
Number of equity offerings & 1,108 & 262 & 45 & 254 & 103 & 1,772 \\
Number of equity offerings of dual-class firms & 72 & 7 & 6 & 25 & 3 & 113 \\
\hline
\end{tabular}

For each equity offering we selected a share of a different firm using a matching procedure to control for systematic factors that could affect liquidity of similar stocks. ${ }^{8}$ Specifically, we set up the following industry-size matching algorithm:

1. Start from a given stock issued in a given date (event).

2. Select stocks of the same industry at GICS 3 digit-level.

3. Exclude stocks of the same issuer.

4. Keep stocks that have been traded, at least, $30 \%$ of trading days of prior month of the event.

5. Select the stock closest in size to the issued stock, as given by the log difference of market caps.

6. In case that two or more stocks meet the above conditions, we select the stock higher average trading volume in the last month.

7. If no stock fulfills these conditions, the procedure is repeated from step 2 with a GICS 2 digitlevel matching.

Table 2 presents summary statistics of our three liquidity measures by country. The liquidity measures are strongly positively skewed, especially Amihud's measure and bid-ask spread. The most liquid market is the Chilean one: it has the lowest Ahmihud's impact prices, the narrowest spreads

\footnotetext{
${ }^{7}$ Some unmatched observations had to be individually identified and manually matched.

${ }^{8}$ Similar to Kothare (1997), Bilinski et al. (2012) and Eckbo \& Norli (2005), who investigated the liquidity impact of seasoned equity offerings.
} 
and the lowest percentage of days with zeros returns. In fact, this quoted spread of Chilean market is similar to effective spread of NASDAQ, Spain and Australia stock exchanges, as Brockman, Chung \& Pérignon (2009) reported; but spreads of Brazil, Mexico and Peru are much higher than developed countries. $^{9}$

Table 2: Summary statistics of liquidity measures per country

\begin{tabular}{|c|c|c|c|c|c|}
\hline & Brazil & Chile & Colombia & Mexico & Peru \\
\hline \multicolumn{6}{|l|}{ Amihud } \\
\hline Min & 0 & 0 & 0 & 0 & 0.0000133 \\
\hline $\operatorname{Max}$ & 1.327823 & 0.0096467 & 0.0027578 & 0.1022167 & 0.0290234 \\
\hline Mean & 0.0095319 & 0.0002147 & 0.0002812 & 0.0017601 & 0.0011391 \\
\hline Percentile 25 & 0.0000007 & 0.0000003 & 0.0000004 & 0.0000007 & 0.0000926 \\
\hline Percentile 50 & 0.0000853 & 0.0000108 & 0.0000237 & 0.0000675 & 0.000194 \\
\hline Percentile 75 & 0.0018117 & 0.0001194 & 0.0001807 & 0.0005504 & 0.0004323 \\
\hline \multicolumn{6}{|l|}{ Bid-ask spread } \\
\hline Min & 0.0011606 & 0.0022553 & & 0.0015234 & 0.0048532 \\
\hline $\operatorname{Max}$ & 0.7256513 & 0.12517 & & 0.2534381 & 0.0738293 \\
\hline Mean & 0.0600401 & 0.0107377 & & 0.0281716 & 0.0218853 \\
\hline Percentile 25 & 0.0085592 & 0.0047681 & & 0.0072613 & 0.0123463 \\
\hline Percentile 50 & 0.0236118 & 0.0065479 & & 0.016277 & 0.0179648 \\
\hline Percentile 75 & 0.0720114 & 0.0089742 & & 0.0364458 & 0.0284121 \\
\hline \multicolumn{6}{|l|}{ Zeros } \\
\hline Min & 0 & 0 & 0 & 0 & 0 \\
\hline $\operatorname{Max}$ & 0.7368421 & 0.5909091 & 0.3636364 & 0.85 & 0.4347826 \\
\hline Mean & 0.0755761 & 0.053473 & 0.0922521 & 0.0532169 & 0.1868215 \\
\hline Percentile 25 & 0 & 0 & 0 & 0 & 0.05 \\
\hline Percentile 50 & 0.0434783 & 0 & 0.0909091 & 0 & 0.1904762 \\
\hline Percentile 75 & 0.1 & 0.05 & 0.1428571 & 0.0869565 & 0.2857143 \\
\hline
\end{tabular}

We run a panel-data econometric model in event time. The event is defined as the moment in which an equity offering occurs (IPO or SEO) in a firm with at least one associated dual-class share. The pre-event window is 12 months prior, and the post-event window is 12 months after the equity offering. If $i$ is the analyzed stock (either the associated dual-class or the control share), the econometric model for the event study is as follows:

$$
\begin{aligned}
\text { Illiquidity }_{i t}= & \alpha_{0}+\alpha_{1 i}+\delta\left(\text { After offering }_{t} \times \text { Dual }_{i}\right) \\
& +\gamma(\text { After offering } \\
& \left.\times \text { Control }_{i}\right)+\boldsymbol{x}_{i t}^{\prime} \boldsymbol{\beta}+\varepsilon_{i t}
\end{aligned}
$$

where $t=-12,-11, \ldots, 0, \ldots, 11,12$ months and $t=0$ identifies the event date; Illiquidity $_{i t}$ is, alternatively, the Amihud's measure in $\operatorname{logs}$, the bid-ask spread in $\operatorname{logs}{ }^{10}$ and the Zero daily return; ${ }^{11}$

\footnotetext{
${ }^{9}$ Datastream doesn't include quote data for Colombia.

${ }^{10}$ To guarantee nonnegative results, the log operator is applied after adding the unity, it is $\ln (1+$ Illiquidity) .

${ }^{11}$ It is called "illiquidity" because all of the three liquidity measures rise when the liquidity is lower.
} 
After offering $_{t}$ is a dummy variable that take the value of zero before the event date and the value of 1 after the event date; Dual $_{i}$ is a dummy variable that takes the value of 1 for the associated dualclass share and zero otherwise; Control $_{i}$ is a dummy variable that takes the value of 1 for matched control share and zero otherwise; and $\boldsymbol{x}_{i t}^{\prime}$ is a vector of control variables.

If an equity offering cause a negative impact over the associated dual-class share, we expect a positive sign of $\delta$ coefficient. Also, as the matched share is not likely to be affected by the equity offering, we expect $\gamma$ to be not statistically significant. Following the literature (Chung, Elder, \& Kim, 2010; Grullon, Kanatas, \& Weston, 2004; Kryzanowski et al., 2010; Rhee \& Wang, 2009; Sankaraguruswamy, Shen, \& Yamada, 2013), we use the following stock-month control variables: volume traded (in logs), for which we expect a negative sign (higher liquidity); volatility, which should have a positive sign; return, which should have a negative sign; and price (in logs) which we expect to have a negative sign.

\section{Results}

Table 3 presents the main results of the regression analysis of the model. As can be seen in columns 1 and 3, illiquidity of dual-class shares rises after an equity offering of the same issuer: both coefficients are positive and highly significant, which means that impact price and the percentage of days with zero return increase. However, it cannot be proven using bid-ask spread as liquidity proxy. On the other hand, matched shares liquidity do not seem to be affected by the equity offering, as expected; the coefficients are not statistically significant, except of Zeros measure, but only at $10 \%$ significance level.

Most of the rest of coefficient signs are as expected. The higher volume, the less illiquid shares are, except with Zeros measure. Volatility increases illiquidity, but with Zeros measure it shows the opposite sign. This could be explained as an estimation bias, because when Zeros are high, there are no enough data to properly calculate the standard deviation of the returns. The sign and significance of return coefficient are as expected only for bid-ask spread: when returns are positive (negative), illiquidity reduces (increases). Finally, the sign and significance of price coefficient are as expected only for Zeros measure.

The panel-data was estimated with individual fixed effects. A joint-test of country fixed effects did not showed to be significant. We also tested the significance of differential effect of the event over stock liquidity, using interaction of country dummies with After offering $_{t} \times$ Dual $_{i}$, but it also proved to be insignificant. 
Table 3: Panel-data regressions of event studies around equity offerings and their impact on dual-class shares' liquidity

\begin{tabular}{|c|c|c|c|}
\hline Dep. variable & $\begin{array}{c}(1) \\
\ln (\text { Amihud })\end{array}$ & $\begin{array}{c}(2) \\
\ln (\text { BA Spread) }\end{array}$ & $\begin{array}{c}(3) \\
\text { Zeros }\end{array}$ \\
\hline After offering ${ }_{t} \times$ Dual $_{i}$ & $\begin{array}{c}0.0055 * * * \\
(0.0016)\end{array}$ & $\begin{array}{l}-0.0015 \\
(0.0019)\end{array}$ & $\begin{array}{c}0.0280 * * * \\
(0.006)\end{array}$ \\
\hline After offering $t \times$ Control $_{i}$ & $\begin{array}{l}0.0003 \\
(0.0012)\end{array}$ & $\begin{array}{l}0.0021 \\
(0.0013)\end{array}$ & $\begin{array}{c}-0.0089 * \\
(0.0043)\end{array}$ \\
\hline $\ln$ Volume $_{i t}$ & $\begin{array}{c}-0.0050 * * * \\
(0.0005)\end{array}$ & $\begin{array}{c}-0.0084 * * * \\
(0.0006)\end{array}$ & $\begin{array}{c}-0.0014 \\
(0.0018)\end{array}$ \\
\hline Volatility $_{i t}$ & $\begin{array}{c}0.0134 * * * \\
(0.0017)\end{array}$ & $\begin{array}{c}0.0141 * * * \\
(0.0019)\end{array}$ & $\begin{array}{c}-0.0776 * * * \\
(0.0063)\end{array}$ \\
\hline Return $_{i t}$ & $\begin{array}{l}-0.006 \\
(0.0035)\end{array}$ & $\begin{array}{c}-0.0098 * * \\
(0.0038)\end{array}$ & $\begin{array}{l}0.0265 * \\
(0.0126)\end{array}$ \\
\hline $\ln$ Price $_{i t}$ & $\begin{array}{l}-0.0017 \\
(0.0023)\end{array}$ & $\begin{array}{l}0.0015 \\
(0.0025)\end{array}$ & $\begin{array}{c}-0.0224 * * \\
(0.0085)\end{array}$ \\
\hline $\begin{array}{l}\mathrm{N} \\
\mathrm{R} 2 \\
\text { Log likelihood }\end{array}$ & $\begin{array}{c}2764 \\
0.0653 \\
6533.3946 \\
\end{array}$ & $\begin{array}{c}2324 \\
0.1257 \\
5440.4484\end{array}$ & $\begin{array}{c}2764 \\
0.0851 \\
2969.4796\end{array}$ \\
\hline \multicolumn{4}{|c|}{$\begin{array}{l}\text { The table reports estimates from panel-data regressions of dual-class shares liquidity as an event study around the equity } \\
\text { offering of a share of the same issuer. The frequency is monthly and the event window starts } 12 \text { months before the event } \\
\text { and ends } 12 \text { months after the event. Liquidity is measured by the log of monthly average Amihud's impact price measure } \\
\text { (column } 1 \text { ), the log of monthly quoted bid-ask spread (column } 2 \text { ) and the monthly Zero daily returns (column } 3 \text { ). After } \\
\text { offering } t \text { is a dummy variable that take the value of zero before the event date and the value of } 1 \text { after the event date. Dual } i \\
\text { is a dummy variable that takes the value of } 1 \text { if the analyzed share is the dual-class associated to the event and zero otherwise. } \\
\text { Control is a dummy variable that takes the value of } 1 \text { if the analyzed share is the matched control share associated to the } \\
\text { event and zero otherwise. Volume it is the total money traded of the share during the month. Volatilityit is de sample standard } \\
\text { deviation of daily log return during the month. Returnit is the monthly log return of the share. ln Priceit is the log of the last } \\
\text { price of the month. The panel data was estimated with fixed effects. Robust standard errors are presented in parenthesis. } \\
\text { The symbols } * * *, * * \text { and } * \text { denote significance at } 1 \%, 5 \% \text { and } 10 \% \text { level, respectively. }\end{array}$} \\
\hline
\end{tabular}

Additionally, to take into account the possible endogenous relation between liquidity and trading volume, we also estimated the model using the first lag of the latter as instrumental variable. The results are presented in Table 4. This kind of estimation could be accomplished because of the absence of autocorrelation proved through a Wooldridge test. The results do not differ from previous estimation; there are only some changes in control variables coefficients significance. 
Table 4: Panel-data regressions of event studies around equity offerings and their impact on dual-class shares' liquidity using instrumental variables

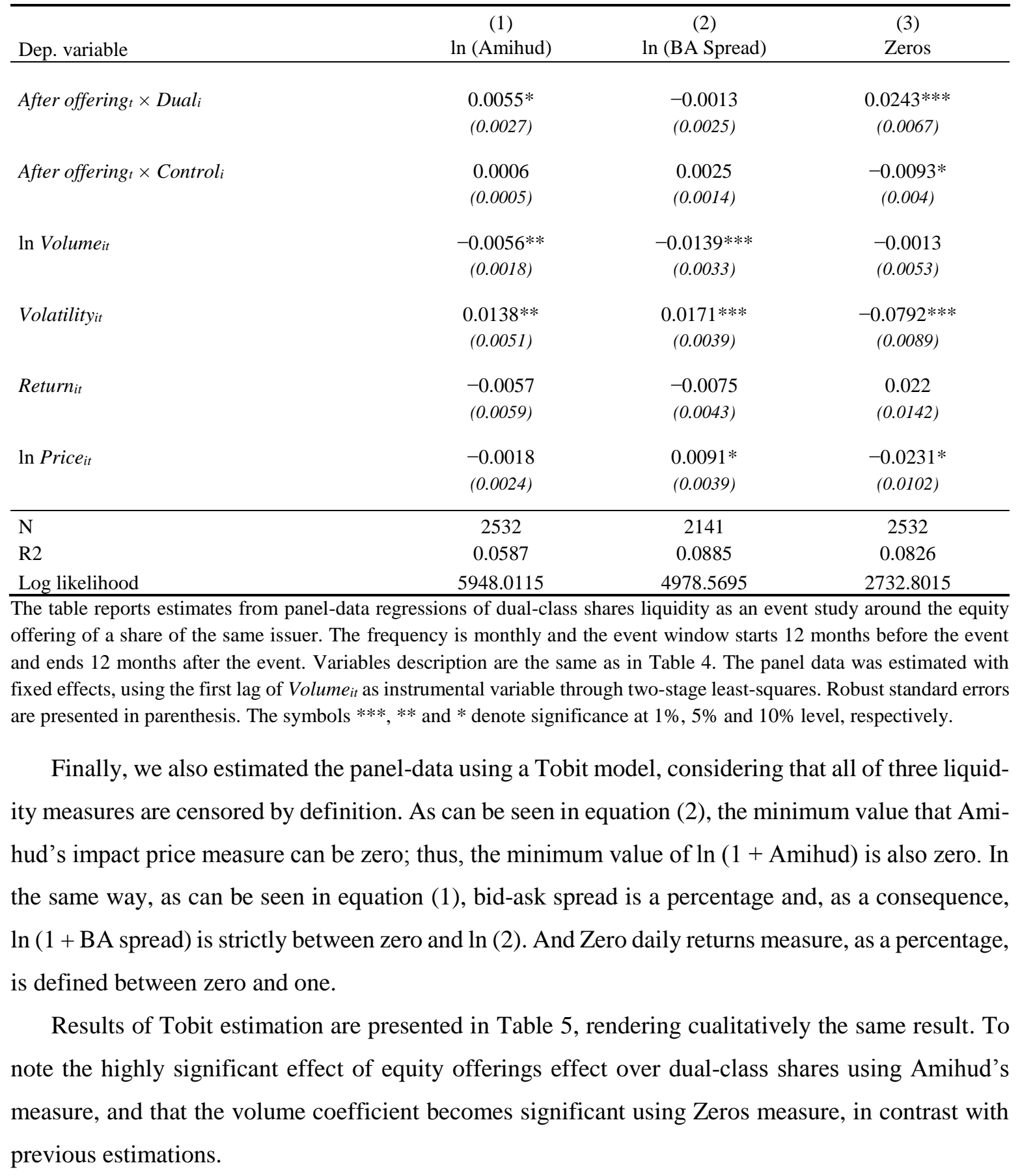


Table 5: Panel-data regressions of event studies around equity offerings and their impact on dual-class shares' liquidity using Tobit estimation

\begin{tabular}{|c|c|c|c|}
\hline Dep. variable & $\begin{array}{c}(1) \\
\ln (\text { Amihud })\end{array}$ & $\begin{array}{c}(2) \\
\ln (\text { BA Spread) }\end{array}$ & $\begin{array}{c}(3) \\
\text { Zeros }\end{array}$ \\
\hline After offering $_{t} \times$ Dual $_{i}$ & $\begin{array}{c}0.0059 * * * \\
(0.0016)\end{array}$ & $\begin{array}{l}0.0004 \\
(0.0019)\end{array}$ & $\begin{array}{c}0.0287 * * * \\
(0.0072)\end{array}$ \\
\hline After offering ${ }_{t} \times$ Control $_{i}$ & $\begin{array}{c}0.0005 \\
(0.0012)\end{array}$ & $\begin{array}{c}0.0018 \\
(0.0013)\end{array}$ & $\begin{array}{l}-0.0095 \\
(0.0054)\end{array}$ \\
\hline $\ln$ Volume $_{i t}$ & $\begin{array}{c}-0.0047 * * * \\
(0.0004)\end{array}$ & $\begin{array}{c}-0.0096 * * * \\
(0.0005)\end{array}$ & $\begin{array}{c}-0.0053^{* *} \\
(0.0018)\end{array}$ \\
\hline Volatility $_{i t}$ & $\begin{array}{c}0.0147 * * * \\
(0.0017)\end{array}$ & $\begin{array}{c}0.0170 * * * \\
(0.0018)\end{array}$ & $\begin{array}{c}-0.0938 * * * \\
(0.0079)\end{array}$ \\
\hline Return $_{i t}$ & $\begin{array}{r}-0.0063 \\
(0.0035)\end{array}$ & $\begin{array}{c}-0.0092 * \\
(0.0038)\end{array}$ & $\begin{array}{c}0.0483^{* *} \\
(0.0161)\end{array}$ \\
\hline $\ln$ Price $_{i t}$ & $\begin{array}{l}-0.0025 \\
(0.0017)\end{array}$ & $\begin{array}{l}0.0035 * \\
(0.0016)\end{array}$ & $\begin{array}{c}-0.0225^{* * *} \\
(0.0068)\end{array}$ \\
\hline $\begin{array}{l}\mathrm{N} \\
\text { Log likelihood }\end{array}$ & $\begin{array}{c}2764 \\
6198.7168\end{array}$ & $\begin{array}{c}2324 \\
5216.4142\end{array}$ & $\begin{array}{c}2764 \\
1144.5291 \\
\end{array}$ \\
\hline $\begin{array}{l}\text { The table reports estimates } \\
\text { offering of a share of the s } \\
\text { and ends } 12 \text { months after } t \\
\text { Tobit estimation and rando } \\
\text { (2); lower and upper limits } \\
* * * * * \text { and } * \text { denote signif }\end{array}$ & $\begin{array}{l}\text { ons of dual-cla } \\
\text { is monthly ar } \\
\text { iption are the s } \\
\text { column } 1 \text { is ze } \\
\text { one. Robust sta } \\
\text { level, respect }\end{array}$ & $\begin{array}{l}\text { liquidity as an e } \\
\text { ent window start } \\
n \text { Table } 4 \text {. The p } \\
r \text { and upper limit } \\
\text { rors are presentec }\end{array}$ & $\begin{array}{l}\text { y around the } \\
\text { ths before th } \\
\text { was estimat } \\
\text { in } 2 \text { are zero } \\
\text { thesis. The s }\end{array}$ \\
\hline
\end{tabular}

\section{Conclusions}

One of the main advantages to raise capital through issuing shares is the stock liquidity improvement, which finally benefits the cost of capital and the firm value. However, if the company is a dual-class firm, the final result might be more complicated. In this paper we provide evidence that after an equity offering, the liquidity of an associated dual-class share decreases, probably because of migration of traders from the associated dual-class shares to the just issued one. We use dual-class firms and equity offerings from five Latin American countries, a region with an intensive use of dual-class shares. This negative spillover effect should be taken into account by managers, when deciding to raise capital, and by investors because they could face unexpected trading costs.

For future research, it could be interesting to extend this study to other countries. Also, analyze the effect of this liquidity spillover more in depth using the bid-ask spread decomposition, which require intraday data (George, 1991; Huang, 1997). 


\section{References}

Akerlof, G. A. (1970). The Market for "Lemons": Quality Uncertainty and the Market Mechanism. The Quarterly Journal of Economics, 84(3), 488-500.

Amihud, Y. (2002). Illiquidity and stock returns: cross-section and time-series effects. Journal of Financial Markets, 5(1), 31-56.

Amihud, Y., \& Mendelson, H. (1980). Dealership market: Market-making with inventory. Journal of Financial Economics, 8(1), 31-53.

Amihud, Y., \& Mendelson, H. (1986a). Asset pricing and the bid-ask spread. Journal of Financial Economics, 17(2), 223-249.

Amihud, Y., \& Mendelson, H. (1986b). Liquidity and stock returns. Financial Analysts Journal, 42(3), 43-48.

Amihud, Y., \& Mendelson, H. (1988). Liquidity and Asset Prices: Financial Management Implications. Financial Management, 17(1), 5-15.

Ang, J., Chua, A., \& Jiang, D. (2010). Is A Better than B? How Affect Influences the Marketing and Pricing of Financial Securities. Financial Analysts Journal, 66(6), 1-16.

Bagehot, W. (1971). The only game in town. Financial Analysts Journal, 27(2), 12-22.

Bekaert, G., Harvey, C. R., \& Lundblad, C. (2007). Liquidity and expected returns: Lessons from emerging markets. Review of Financial Studies, 20(6), 1783-1831.

Bilinski, P., Liu, W., \& Strong, N. (2012). Does liquidity risk explain low firm performance following seasoned equity offerings? Journal of Banking \& Finance, 36(10), 2770-2785.

Brockman, P., Chung, D. Y., \& Pérignon, C. (2009). Commonality in Liquidity: A Global Perspective. Journal of Financial and Quantitative Analysis, 44(04), 851.

Brooks, R. M., \& Patel, A. (2000). Information conveyed by seasoned security offerings: evidence from components of the bid-ask spread. Review of Financial Economics, 9(2), 83-99.

Chung, K. H., Elder, J., \& Kim, J.-C. (2010). Corporate Governance and Liquidity. Journal of Financial and Quantitative Analysis, 45(02), 265-291.

Copeland, T. E., \& Galai, D. (1983). Information Effects on the Bid-Ask Spread. The Journal of Finance, 38(5), 1457-1469.

Doidge, C. (2004). U.S. cross-listings and the private benefits of control: evidence from dual-class firms. Journal of Financial Economics, 72(3), 519-553.

Dyck, A., \& Zingales, L. (2004). Private benefits of control: An international comparison. The Journal of Finance, LIX(2), 537-600.

Eckbo, B. E., Masulis, R. W., \& Norli, Ø. (2000). Seasoned public offerings: Resolution of the "new issues puzzle." Journal of Financial Economics, 56(2), 251-291.

Eckbo, B. E., \& Norli, Ø. (2005). Liquidity risk, leverage and long-run IPO returns. Journal of Corporate Finance, 11(1-2), 1-35.

George, T. J. (1991). Estimation of the bid-ask spread and its components: a new approach. Review of Financial Studies, 4(4), 623-656.

Glosten, L. R., \& Milgrom, P. R. (1985). Bid, ask and transaction prices in a specialist market with heterogeneously informed traders. Journal of Financial Economics, 14(1), 71-100.

Goyenko, R. Y., Holden, C. W., \& Trzcinka, C. a. (2009). Do liquidity measures measure liquidity? Journal of Financial Economics, 92(2), 153-181.

Grossman, S. J., \& Miller, M. H. (1988). Liquidity and Market Structure. The Journal of Finance, 43(3), 617-633.

Grullon, G., Kanatas, G., \& Weston, J. P. (2004). Advertising, Breadth of Ownership, and Liquidity. Review of Financial Studies, 17(2), 439-461.

Ho, T. S. Y., \& Stoll, H. R. (1981). Optimal dealer pricing under transactions and return uncertainty. Journal of Financial Economics, 9(1), 47-73. 
Ho, T. S. Y., \& Stoll, H. R. (1983). The Dynamics of Dealer Markets Under Competition. The Journal of Finance, 38(4), 1053-1074.

Huang, R. D. (1997). The components of the bid-ask spread: a general approach. Review of Financial Studies, 10(4), 995-1034.

Kothare, M. (1997). The effects of equity issues on ownership structure and stock liquidity: A comparison of rights and public offerings. Journal of Financial Economics, 43(1), 131-148.

Kryzanowski, L., Lazrak, S., \& Rakita, I. (2010). Behavior of liquidity and returns around Canadian seasoned equity offerings. Journal of Banking \& Finance, 34(12), 2954-2967.

Kyle, A. S. (1985). Continuous Auctions and Insider Trading. Econometrica, 53(6), 1315-1335.

Lease, R. C., Masulis, R. W., \& Page, J. R. (1991). An investigation of market microstructure impacts on event study returns. The Journal of Finance, XLVI(4), 1523-1537.

Lee, K.-H. (2011). The world price of liquidity risk. Journal of Financial Economics, 99(1), 136161.

Lesmond, D. A. (2005). Liquidity of emerging markets. Journal of Financial Economics, 77(2), 411452.

Lesmond, D. A., Ogden, J. P., \& Trzcinka, C. A. (1999). A new estimate of transaction costs. Review of Financial Studies, 12(5), 1113-1141.

Levine, R., \& Schmukler, S. L. (2006). Internationalization and Stock Market Liquidity. Review of Finance, 10(1), 153-187.

Levy, H. (1983). Economic evaluation of voting power of common stock. The Journal of Finance, XXXVIII(1), 79-93.

Masulis, R. W., Pham, P. K., \& Zein, J. (2011). Family Business Groups around the World: Financing Advantages, Control Motivations, and Organizational Choices. Review of Financial Studies, 24(11), 3556-3600.

Nenova, T. (2001). How to Dominate a Firm With Valuable Control? Dual Class Firms Around the World: Regulation, Security-Voting Structure, and Ownership Patterns (pp. 1-26). Retrieved from http://papers.ssrn.com/sol3/papers.cfm?abstract_id=1017603

Nenova, T. (2003). The value of corporate voting rights and control: A cross-country analysis. Journal of Financial Economics, 68(3), 325-351.

Ødegaard, B. A. (2007). Price differences between equity classes. Corporate control, foreign ownership or liquidity? Journal of Banking \& Finance, 31(12), 3621-3645.

Rhee, S. G., \& Wang, J. (2009). Foreign institutional ownership and stock market liquidity: Evidence from Indonesia. Journal of Banking \& Finance, 33(7), 1312-1324.

Rubin, A. (2007). Ownership level, ownership concentration and liquidity. Journal of Financial Markets, 10(3), 219-248.

Sankaraguruswamy, S., Shen, J., \& Yamada, T. (2013). The relationship between the frequency of news release and the information asymmetry: The role of uninformed trading. Journal of Banking \& Finance, 37(11), 4134-4143.

Smith, B. F., \& Amoako-Adu, B. (1995). Relative prices of dual class shares. Journal of Financial and Quantitative Analysis, 30(2), 223-239.

Tripathy, N., \& Rao, R. P. (1992). Adverse selection, spread behavior, and over-the-counter seasoned equity offerings. Journal of Financial Research, XV(1), 39-56. 